\title{
Burrowing and mud-mound building life habits of fiddler crab Uca lactea in the Bay of Bengal coast, India and their geological and geotechnical importance
}

\author{
Chandreyee De
}

\begin{abstract}
Burrowing and mud mound-building life-habits of quasiterrestrial fiddler crab Uca lactea from Bengal coast under specific substrate (soft aqueous mud deceptively occurring below rigid sand), hydrodynamic (low-energy and shallow inundation) and geomorphic (coastal mudflats around estuary mouth) conditions are addressed to evaluate geological and geotechnical importance. They construct mud-mounds at burrow (simple, I-shaped and un-branched) heads during tidal recession through oozing out of burrow-base mud-slur. Depth of tidal inundation and substrate undulations control mound population, height and types (dominance of short simple-mounds in highgrounds vs. tall compound-mounds in low-grounds allowing subaerial respiration). Loss of dwelling habitat through mound collapse during high tide is promptly compensated by new constructions. Microbial stabilization of mounds through seasonal algal bloom enhances their preservation under freshly deposited sand layers. They also produce mud-chimneys and feeding-pellets in association with Turritella spp. trails and worm burrows.

Despite considerable preservation potentiality of Uca mud-mounds their exact ancient analogues are not yet known. The study provides firsthand criteria to recognize fossil burrows and mud-mounds of Uca and comparative analysis between $U$. marionis mud-volcanoes and $U$. lactea mud-mounds. Morphologically they are identical enough to constitute a unique ichnotaxon. The studied ichnocoenose corresponds in fossil records to Skolithos-Taphrhelminthopsis-Ophiomorpha-Planolites-Thalassinoides association within shallow marine Psilonichnus ichnofacies to which Uca mud-mounds are new entrants diagnostic of palaeoshoreline, especially shallow coastal-mudflats at high-tide level. Uca mud-mounds, by virtue of requirement of unique substrate conditions, are considered as ichnological indicators of erosion-prone coastal segments. Their global zoogeographic distribution allows wide application of this ichnological tool.
\end{abstract}

Chandreyee De. Department of Earth Sciences, Presidency University, Kolkata, 11 Ujjal park, post officeBrahmapur, Kolkata 700096, West Bengal, India chandreyee_de@yahoo.co.in

Keywords: Uca lactea; burrows; mud-mound; Bay of Bengal coast; geology; geotechnology

PE Article Number: 18.2.26A

Copyright: Palaeontological Association May 2015

Submission: 13 August 2013. Acceptance: 30 April 2015

De, Chandreyee 2015. Burrowing and mud-mound building life habits of fiddler crab Uca lactea in the Bay of Bengal coast, India and their geological and geotechnical importance. Palaeontologia Electronica 18.2.26A: 1-22

palaeo-electronica.org/content/2015/1196-uca-lactea-mud-mounds 


\section{INTRODUCTION}

Fiddler or calling crabs constitute a unique group of semi-terrestrial and small-sized (maximum $5 \mathrm{~cm}$ across) shallow marine decapods including approximately 100 species belonging to the genus Uca (Rosenberg, 2001). They are easily recognized by their distinctively asymmetric claws. They thrive in large numbers in soft silty to muddy substrates of sea beaches, brackish inter-tidal mudflats, lagoons, backswamps, mangroves, salt marshes, estuaries and creek banks. They have a wide zoogeographic distribution covering the West African, Western Atlantic, Eastern Pacific and IndoPacific regions. Nearly all members of Uca are prodigious burrowers. Their burrowing activities promote nutrient cycling in ecosystems (Mokhtari et al., 2008). The burrowing life habits of some species of Uca have been studied in detail from various modern shallow marine environments including those of North Carolina, Aldabra Atoll, Seychelles and Andros islands of the Bahamas (Basan and Frey, 1977). One meter long simple Uca burrows from high tide zone of Pacific Bays (Ricketts and Calvin, 1962); J-shaped U. pugnax (Smith, 1870) burrows from intertidal mudflat at Doboy Sound, USA (Mayou and Howard, 1975); Ishaped burrows of $U$. minax (Le Conte, 1855), $U$. pugnax and U. pusilator (Bosc, 1802) from supratidal west coast of Florida, Sapelo Island, Georgia and New England marsh (Howard and Frey, 1975; Basan and Frey, 1977; Christy, 1982; Bertness and Miller, 1984) and ontogeny based I-shaped burrows, chimneys and mud volcanoes constructed by $U$. marionis (Alcock, 1900) from Bay of Bengal coast (De and Bakshi, 1981; De, 2009) are reported. Gusmão-Junior et al., (2012) described burrow chimneys of $U$. thayeri (Rathbun, 1900) from south of São Paulo, Brazil. Burrow morphology of Ocypodidae U. ruguayensis (Nobili, 1901) and $U$. leptodactylus (Rathbun, 1898) from subtropical mangrove-forested western Atlantic beaches (Machado et al., 2013) and Uca tangeri (Eydoux, 1835) from Ria Formosa, Portugal (Wolfrath, 1992) have been addressed.

Uca lactea (de Haan, 1835) possesses one of the four widest zoogeographic ranges of fiddler crabs on earth and forms perhaps the most abundant species (Crane, 1975). Uca lactea harbor in mangrove vegetated muddy shores facing large bays or open sea and estuary banks of tropical and subtropical regions including Indo-Pacific coasts, eastern Africa, Samoa, Massawa in the Red Sea, Karachi in Pakistan, southern Japan, China, South Korea, Western Australia and Tonga in the South
Pacific (Crane, 1975). In spite of having a wide distribution and prolific burrowing life habit, the organo-sedimentary features (lebensspuren) produced by $U$. lactea are relatively underrepresented in published databases as compared to other species of Uca. Only their population ecology (Mokhtari et al., 2008), semilunar courtship rhythm vs. tidal variation (Kima et al., 2004), behavioural ecology (Bones, 1983), territory usage vs. defense mechanism (Yamaguchi and Sugakiri, 2004) and the formation of low semidome structures at burrow mouths as visual landmarks (Kima et al., 2010) are known.

True crabs appeared post Jurassic (Frey et al., 1984). Post-Jurassic coastal marine sediments preserve a wide range of lebensspuren, such as burrows, burrow-head sediment mounds/domes/ chimneys, fecal and feeding pellets, trackways, resting traces and scratch marks of crab origin. Many of them represent ancient analogues of modern lebensspuren produced by quasiterrestrial fiddler crabs and are useful in palaeoenvironmental, palaeogeomorphic and palaeoecological interpretations, besides hydrocarbon prospecting (Curran and Frey, 1977; Frey et al., 1984; Humphreys and Balson, 1988; Curran and White, 1991; Chakraborti and Hertweck, 1992; Pemberton et al., 1992; Chakraborti, 1993; Mángano et al., 1994; Buatois et al., 1998; Gingras et al., 1999, 2000; Buatois and Mángano, 2000; De, 2000, 2005). Moreover, most commonly interpreted ancient crab burrowers are Ocypode, Ilyoplax, Uca and Cardisoma (Shinn, 1968). Psilonichnus and to some extent Skolithos ichnofacies are characterized by shallow marine (littoral) amphibious crab burrows (Pemberton et al., 1992; Buatois et al., 1998; Buatois and Mángano, 2000). Neoichnological insights of fiddler crabs, thus, become important in various geological interpretations. Besides, such studies do have geotechnical application potential to recognize modern beach sectors highly prone to erosion and transgressive-regressive modes of present sea (De, 1998, 2002a, 2005, 2009; Mallick, 2006).

The prime objectives of the present neoichnological study in the Bay of Bengal coast of eastern India (Figure 1.1-2) are to: 1) record for the first time mud-mounds of Uca lactea origin; 2) reveal their burrowing life habits especially in terms of mud-mounds vis a vis substrate and hydrodynamic conditions; and 3) highlight their geological and geotechnical importance as an effort to contribute new information to the ichnological database. The study also provides a comparative analysis 

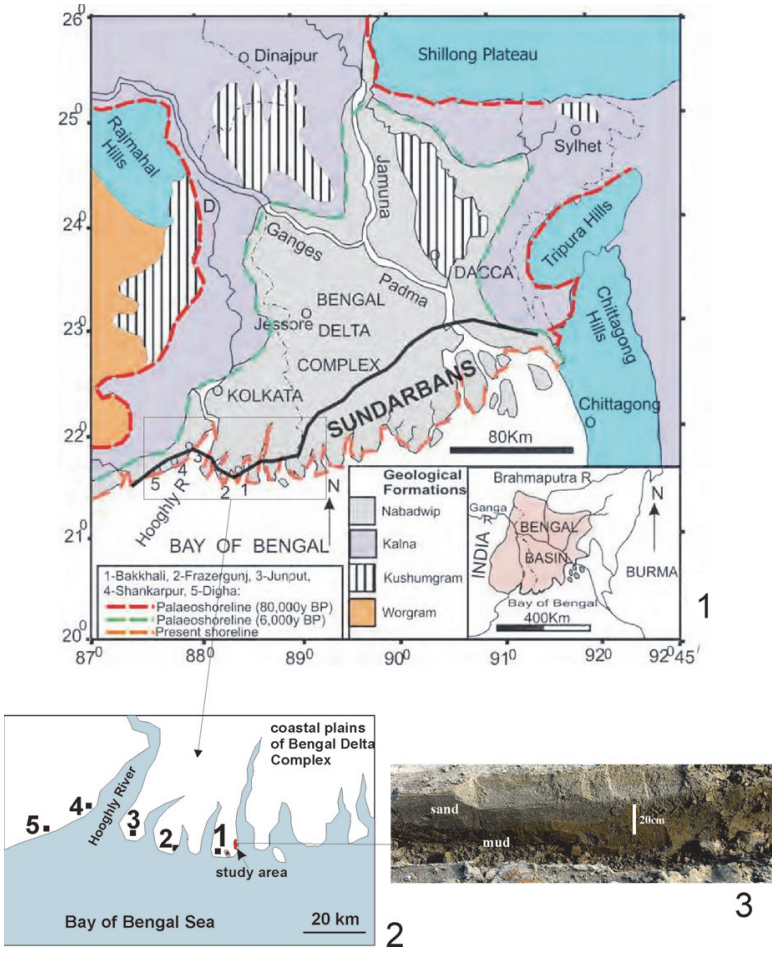

FIGURE 1. 1. Regional geological setting of the Bengal Delta Complex with reference to down drift coastal plains incorporating large area covered by modern mangrove forest of Sundarbans, the Bay of Bengal Sea and Quaternary stratigraphy with time-successive palaeocoastlines (modified after Mallick et al., 1972). Note position of studied Bakkhali beach sector. 2. Magnified view of coastal beach sectors with location of study area (marked by red) by the side of a mighty estuary and position $\left({ }^{*}\right)$ of reported Uca marionis mud volcanoes (De, 2009). 3. A field excavation site from study area showing occurrence of soft mud layers below relatively dry and rigid sand layers with sharp contact as specific substrate condition.

between $U$. lactea mud-mounds and $U$. marionis mud volcanoes (De, 2009) described from the nearby area of the studied beach sector (Figure 1.1-2) as they are structurally and genetically comparable barring some subtle differences.

\section{THE STUDY AREA}

The study area (about $2.5 \mathrm{sq} \mathrm{km}$ ) is situated by the side of a mighty estuary in the Bakkhali beach sector of western coastal plains of the Sundarban Delta Complex, West Bengal, India (Figure 1.1). The regional landforms developed from land to sea include mangrove vegetated mudflat - saltmarsh - backswamp complex (soft clay-silt) traversed by sinuous creeks, younger mobile dunes (medium to fine grey sand) and sand sheets cover- ing older stabilized dunes (coarse to medium, brown oxidized sand), low gradient supratidal and intertidal beaches (sand>silt>clay: calculated $M Z$ 2.65 to $1.5 \mathrm{phi}$ ) and a wide subtidal zone (silt>clay>sand). These are made up of soft sediments belonging to the Recent Nabadwip Formation that covers semi-rigid mudground and hard woodground (mangrove palaeoforest) of the subRecent Kalna Formation (Figure 1.1). The coastal plains experience an average maximum and minimum temperature range of $41^{\circ} \mathrm{C}$ (May-June) and $24^{\circ} \mathrm{C}$ (December), high annual rainfall $(1560 \mathrm{~mm}$ to $2600 \mathrm{~mm}$ ), spring and neap tidal ranges of 6.6-7.8 $\mathrm{m}$ and $2-2.4 \mathrm{~m}$ respectively, high salinity range (26 ppt in the inner vs. 39 ppt in the outer delta) and moderate $\mathrm{pH}(7.5-8.6)$ according to the Port Trust of India database for the last five years. The dissolved oxygen content in open sea ranges from 2.4 $\mathrm{ml} / \mathrm{l}$ to $4.7 \mathrm{ml} / \mathrm{l}$ (Chattopadhaya et al., 1993).

Bakkhali and other western beach sectors of the delta complex (Figure 1.1) have remained the main focus for sedimentological (Mallick et al., 1972; Mallick, 1976; Allison 1998a, 1998b) and neoichnological studies (Chakraborti, 1972, 1981; Bakshi et al., 1980; De and Bakshi, 1981; Chattopadhaya et al., 1993; De, 1997, 1998, 2000, 2002a, 2002b, 2003, 2005, 2009, 2010; Bandopadhaya and De, 2000;). These researchers covered various geological and geotechnical aspects of a wide range of lebensspuren produced by endobenthic invertebrate communities, especially amphibious crabs, polychaetes, bivalves, gastropods, worms and insects. Of these, the study on Uca marionis mud volcanoes (De, 2009) from another estuary bank locality of the Bakkhali beach sector (Figure 1.2) has a direct relevance to the present study on the Uca lactea mud-mounds. The study area was visited repeatedly during December 2012.

\section{MATERIALS AND METHODS}

The study materials include sediments from three geomorphic units (backswamp, coastal dune and upper intertidal-supratidal flat) for selective grain size analysis; $U$. lactea mud-mounds $(\mathrm{n}=$ 149), burrows (21 white paraffin wax casts), mud chimneys $(n=10)$ and large number $(>100)$ of surficial feeding pellets for morphological analysis; intimately associated traces produced by organisms other than Uca to define natural biotic association and ichnocoenose (environment diagnostic association of lebensspuren); 30 organic samples for taxonomic and growth stage identification by the zoologists in the Decapoda section of the Zoo- 

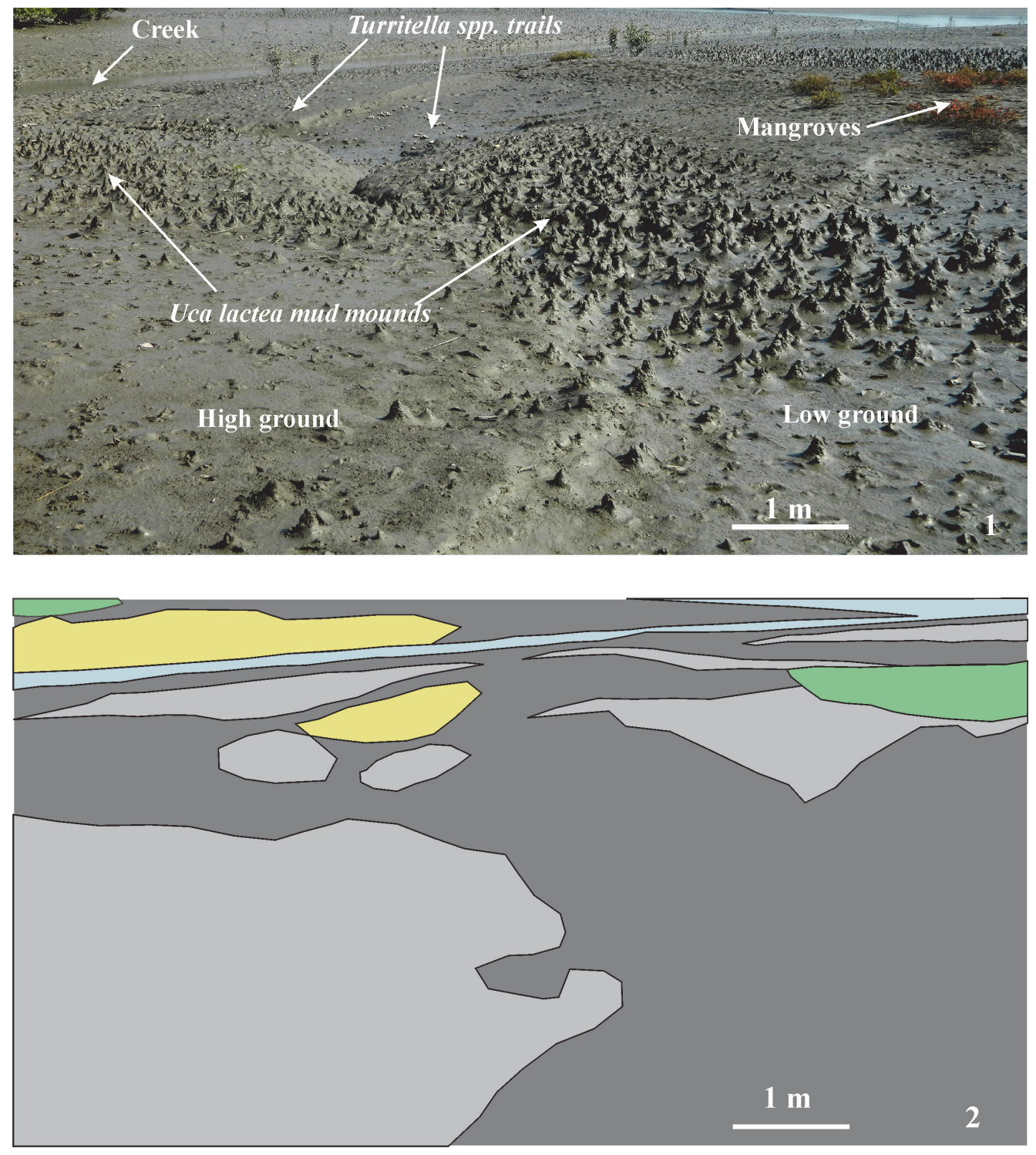

Simple mounds in high ground

Compound mounds in low ground

Turritella spp. trails in low ground

Mangrove plants/bushes

Creek

FIGURE 2. 1. A field photograph of referred sample area for detailed study showing prolific growth of Uca lactea mudmounds on substrate having varied height, presence of mangrove bushes and spread of living Turritella spp. shells and distal creek. 2. Map prepared from sample study area shows distributions of simple mounds in high ground, compound mounds in low ground, Turritella spp. trails in low ground, mangrove bushes/plants and creek.

logical Survey of India, Kolkata; surficial biomats to understand the stabilization process of the lebensspuren and detail photographic documents. A small sample area (about $300 \mathrm{sq} \mathrm{m}$ ) covered by $U$. lactea mud-mounds has been closely studied to understand spatial distribution patterns and architecture of different mud-mound morphotypes relative to high and low grounds, mangrove vegetation and low moist areas with profuse Turritella spp. trails (Figure 2.1-2). The square method was used within this sample area to count physically the number of simple and compound mounds and corresponding number of burrow openings per square meter area. Measurement of vertical heights and serial sectioning of mud-mounds, besides white paraffin casting of 21 burrow cavities were accom- 
plished to understand three dimensional aspects of the mounds relative to burrow cavities. Since the crabs are supersensitive to vibration and sound, it was difficult to count their population density from close points in the field. They are quick enough to escape into subsurface burrows leaving none on the surface. A square method involving sediment excavation or paraffin casting of all burrows and counting of the crabs after proper cleaning would have been highly destructive for the burrowing as well as non-burrowing creatures. Hence, some preselected and measured areas from time to time were telescopically photographed from which the crabs were visually counted to measure their tentative population density. The area was repeatedly visited during low and high tides to observe changes in biogenic activities and mound collapse respectively during periods of sub-aerial exposure and inundation.

\section{LOCAL DISTRIBUTION OF UCA LACTEA}

Of the common trace-producing endobenthic organisms, four species of the genus Ocypode, three of Metaplax and Uca marionis, are best represented as prolific trace-producers (De, 2005) in the studied region. Seven environment-sensitive neoichnological zones have been delineated in this region (De, 2009). The Uca-Turritella zone is characteristic of clay rich backswamp-saltmarsh-mudflat complex and most extensive relative to others. In the Bakkhali beach sector Uca in natural association with Turritella spp. harbor in large numbers selectively in soft mudflats developed around the estuary mouth because of their common mud-loving nature. Uca also explore substrates consisting of soft mud layers covered under thin layers of beach sand. So far, Uca marionis is reported from this area (Deb, 1998; De, 2005, 2009). Uca lactea is being reported from the Uca-Turritella zone of the study area for the first time. Field observation suggests natural disassociation of these two species in the local ecosystem. They define speciesdependent population groups within clay rich backswamp-saltmarsh-mudflat complex. This crab species is well known from many Asian countries including Pakistan (Karachi), southern Japan, China and South Korea (Crane, 1975). The taxonomic discussion is beyond the scope of the present paper as the work concentrates wholly on ichnologic activities (mud-mounds, burrows, chimneys and pellets) of $U$. lactea.

\section{BURROWING LIFE HABITS OF UCA LACTEA}

The introductory references on the zoogeographic distribution, sedimentary facies control and nature of burrows produced by different species of fiddler crab Uca suggest their ubiquitous liking for mangrove-vegetated soft muddy substrate, high salinity and tidal saltmarsh-mudflat-backswamp facies typical of estuarine sub-environment, which in the coastal setting construct simple non-branching I-shaped dwelling burrows. In the study area, Uca lactea is no exception (Figure 3.1-2). They explore the soft muddy substrate of the saltmarshmudflat-backswamp complex and upper river and estuary banks (Figure 2.2). They are not found in the nearby dry sandy beach. They excavate the substrate vertically from top to bottom so as to construct very simple l-shaped non-branching burrows $(1 \mathrm{~cm}$ to $21 \mathrm{~cm}$ long) with a bulbous lower part as revealed from 21 white paraffin wax casts (one juvenile, 10 young, seven adult and three old stage) corresponding to different ontogenetic stages. All the burrows characteristically possess narrow funnel-shaped circular to elliptical aperture exposed on the surface. Burrow density depends directly on population density of the crabs that varies from 4/sq $m$ to $30 / \mathrm{sq} m$ in the study area. The burrow length depends on the depth at which water is available at burrow base for gill moistening, an essential life-saving physiological process. The surficial apertures are protected by excavated materials in various manners. At places the sediments are piled around the opening forming loose sediment heaves or domes (Figure 4.1) for burrow protection in dry areas in the same way as members of crab Ocypode do elsewhere in the adjoining sandy intertidal and supratidal beaches. In the backswamp they construct chimneys $(0.2 \mathrm{~cm}$ to 2.5 $\mathrm{cm}$ high) around the burrow mouth (Figure 4.2) out of excavated mud as a protective measure. Feeding pellets (globular, $1 \mathrm{~mm}$ across) and scratch marks are also produced around the burrow mouth by the side of simple mud-mounds (Figure 4.3). However, a burrow mouth semidome of sediment, as reported to be maintained by $U$. lactea as a visual landmark (Kima et al., 2010), was not observed here. In the study area the most conspicuous burrow mouth feature produced in mudflats by $U$. lactea is the mud-mound, the main concern of this paper.

\section{FORMATION OF UCA LACTEA MUD-MOUNDS}

Mode of formation of Uca lactea mudmounds, their morphological variations with 

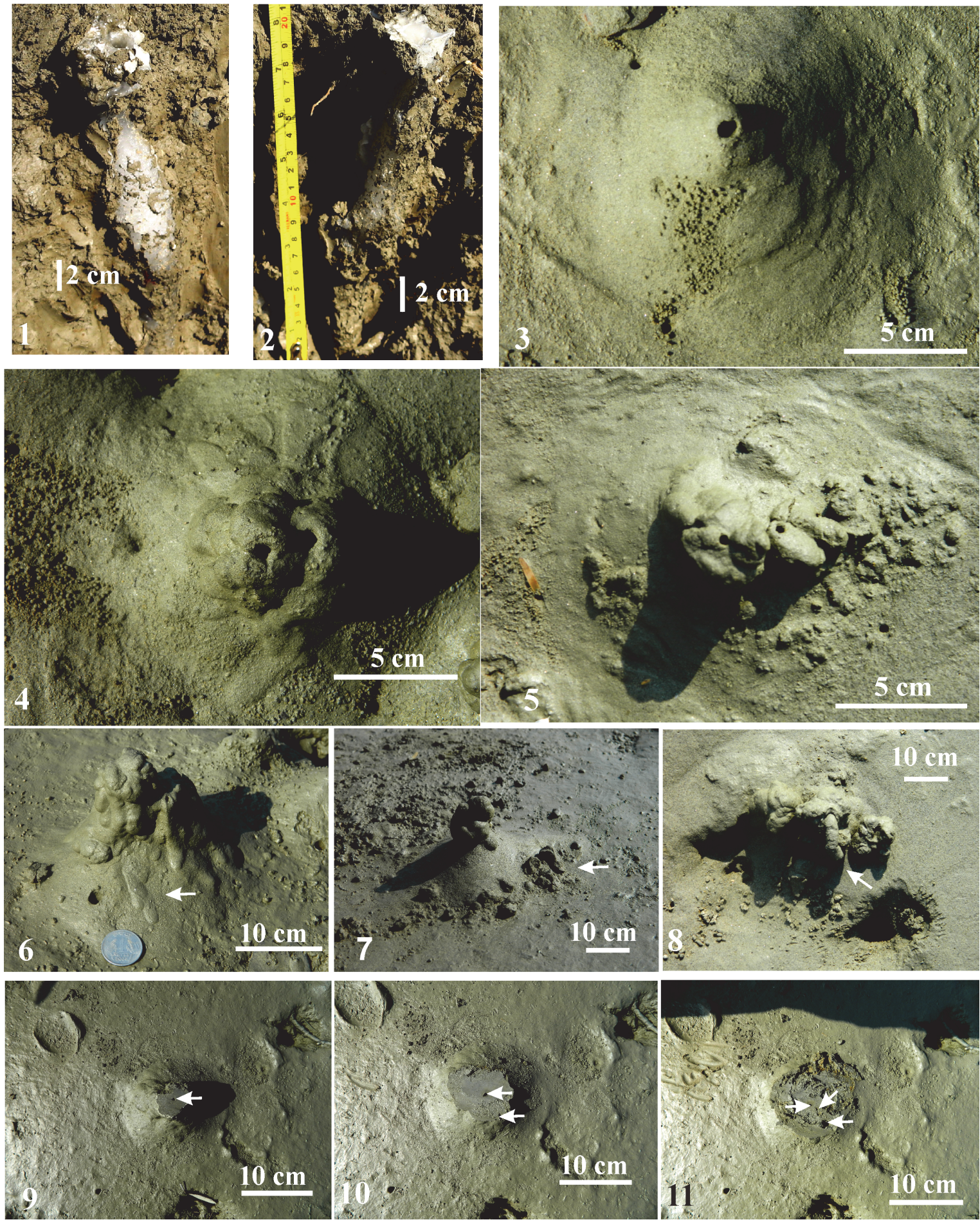

FIGURE 3. 1-2. White paraffin wax casts of the Uca lactea burrows in natural position in the field. Note simple unbranched I-shaped burrow morphology with lower bulged portion and narrow apertural neck. 3. Uca lactea simple mud-mound with a central circular burrow aperture. 4-5. Uca lactea compound mud-mounds with multiple circular to elliptical burrow apertures. 6. A compound mud-mound with projected down mud tongues (arrowed) denoting high water content of the mud slur. 7. Mud-mounds with apertural and rolled out mud lumps (arrowed) indicating low water content of the mud slur. 8. Mud-mound with mud rod (arrowed) ejected out of burrow mouth indicating paste-like viscosity of the mud slur. 9-11. Serial horizontal sections of mud-mound showing successive appearance of burrow openings (arrowed): one in top and three in base level showing downward bulging without any sign of convergence. 

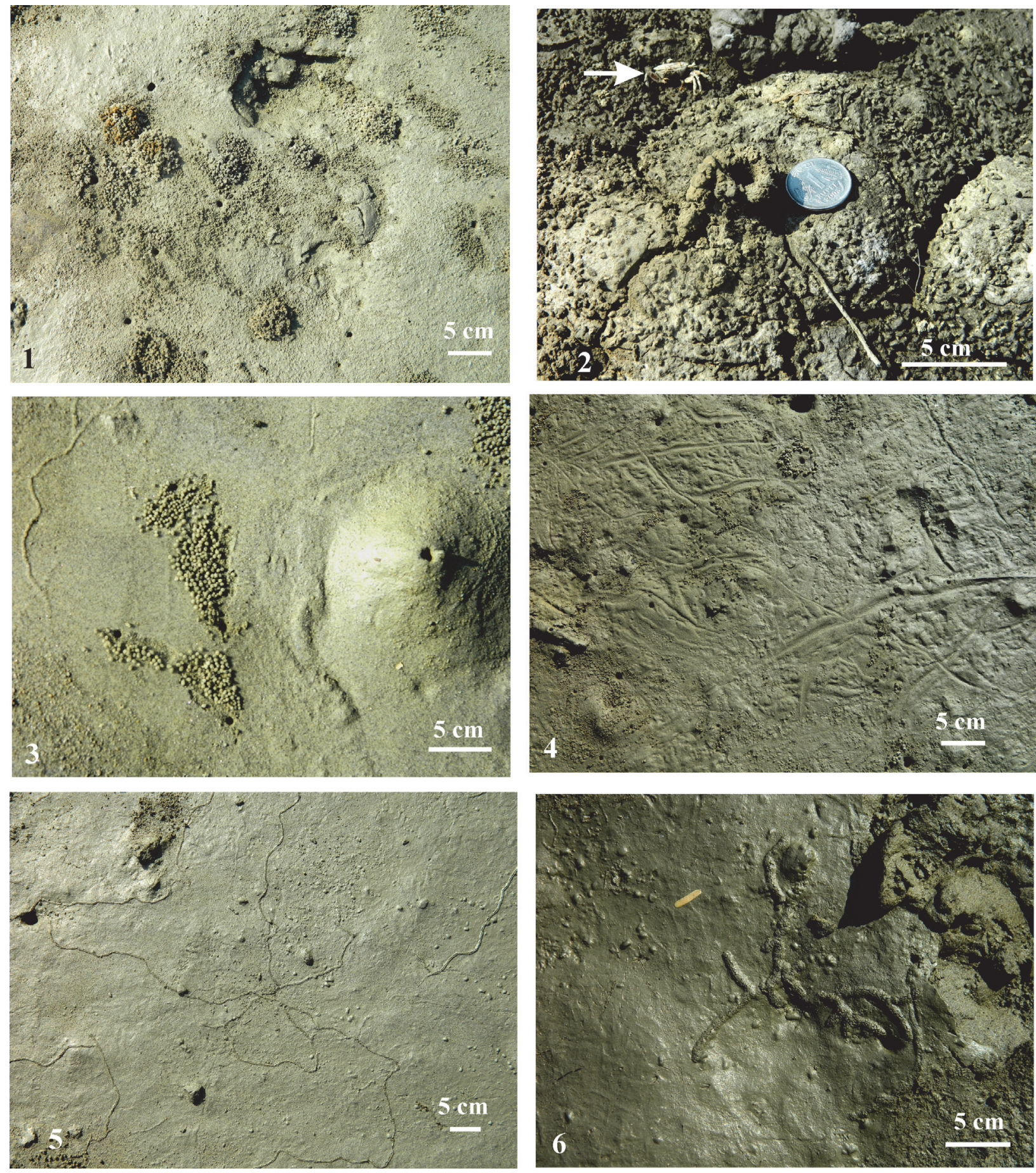

FIGURE 4. 1. Uca lactea burrow mouth with excavated loose sediment heaves or domes in relatively dry area. 2. Uca lactea mud chimney and surrounding substrate with mud clasts derived from collapsed mud-mounds and sorted out by tidal current, mud cracks and one trace producing crab (arrowed). 3. Ideal simple mud-mound of Uca lactea associated with feeding pellets arranged around burrow openings. 4. Network of Turritella spp. trails as observed after tidal wash out in low grounds. 5. Network of non-branching and radiating worm burrows (finer) in exposed and relatively dry mudflat. 6 . Branching worm burrows (thicker) in exposed and relatively dry mudflat. 
respect to high and low grounds, common association of mangroves and other associated biogenic activities have been closely studied with especial reference to sample area (Figure 2.1-2).

\section{Special Substrate Condition}

Uca lactea mud-mounds are produced in a very special substrate condition that exists over a large area in the estuary bank where semi-rigid and fairly dry sand layers (a few $\mathrm{cm}$ to $20 \mathrm{~cm}$ thick as understood from shallow trenching) cover thick layers (few meters) of soft and water-rich mud (Figure 1.3). This mud represents mudflat facies conspicuously developed along the Bay of Bengal coast, especially around estuary mouth areas (De, 2009). Mud-mounds are produced when the depth of the mud layers subsurface is well within the penetration limit (about $20 \mathrm{~cm}$ ) of the crabs as understood from random burrow casting.

\section{Burrowing Process and Mud-Mound Formation}

While burrowing vertically down they penetrate through the top sand layers and eventually reach subsurface moist mud layers. At the burrow base, due to lateral seepage of water, mud slur is produced that tends to accumulate within the burrow cavity. The burrowing crab with the help of its larger claw pushes up the mud slur that oozes out of burrow mouth in repeated pulses so as to form a conical mud-mound on the ground around the burrow opening. The burrow base water serves their purpose of frequent gill moistening for survival. Removal of mud slur keeps the tube unblocked and clear for easy dwelling and passage for the burrowing crab. The height as well as radius of the mud cone increase with repeated oozing out of mud slurs (Figure 5.1-6). The position of the burrow opening is gradually raised so as to accommodate growth of mud-mound and keep burrow mouth clearly open on the surface.

A single conical mound with only one central burrow opening (Figures 3.3, 4.3, 5.1, 6.1) is referred to here as a simple mud-mound. Such mounds predominate in the elevated portions of the estuary bank (Figures 2.1, 6.1-4) and the central burrow is dwelled by a single crab. The outer surface of the cone becomes stepped and knobby (Figure 5.4-6) suggesting repeated pulses of oozing out of mud slur. Mound surface with projected down mud tongues (Figures 3.6, 5.4) suggests higher water content of the internal mud slur. On the contrary, discrete mud lumps and even viscous mud road (Figure 3.7-8) are formed on mound heads where internal mud is more viscous and lower in water content. A compound mound is composed of a main mound, commonly the highest one, and several (three to five) lower sub-mounds around, each of which has a central open burrow opening (Figures 3.4-5, 5.5-6, 6.5-11). The burrow openings are close enough to amalgamate individual mounds into a compound mound (Figure 6.610). Compound mounds are formed predominantly in low ground where population density is high (Figures 2.1, 6.5-11) and are dwelled by several individuals of crab. Higher moistness of the subsurface mud layers in low grounds also contribute to the formation of compound mud-mounds.

The transformation of simple to compound mud-mounds as observed in the field is photographically illustrated in Figure 5.1-6 and the overall mechanism of mound formation is schematically explained in Figure 7. This transformation produces several transitional morphotypes, all having a conspicuous conical shape, made up of mud and a stepped or knobby outer surface with axial burrow tube(s) inside (Figure 6.1-12). Burrow casting (Figure 3.1-2) and serial horizontal sectioning (Figure 3.9-11) of a mound suggest that the burrow shafts are discrete and not connected to each other subsurface, unlike the Uca marionis compound mud volcanoes reported from nearby area (De, 2009). Active formation of mounds, simple or compound, is indicative of the presence of a burrowing crab inside. The mound building process changes a flat substrate to micro-mountainous or rugged topography (Figure 6.1-12) within a few days in the same way as the ocypodid Heloecius cordiformis (Milne-Edwards, 1837) burrow-head mounds do in mangrove swamps near Sydney, Australia (Warren and Underwood, 1986).

\section{Influence of Tidal Action}

During high tide the area remains inundated for a few hours and biogenic activity ceases completely. Just before inundation the burrow opening gets plugged by sediment collapse and a tubular air bubble is formed subsurface within which the crab takes shelter. This biophysical mechanism for intertidal quasiterrestrial crab burrowing is well explained by De (2005) from this region. On recession of water during low tide the substrate gets subaerially exposed for several hours, the burrowers come out of burrows and start biogenic activity afresh either by renovating the earlier domicile or by constructing a new one. Field observations (total six times) immediately after high tide suggest that about $5 \%$ to $10 \%$ of mounds collapse after each high tide forming shallow bowl shaped 

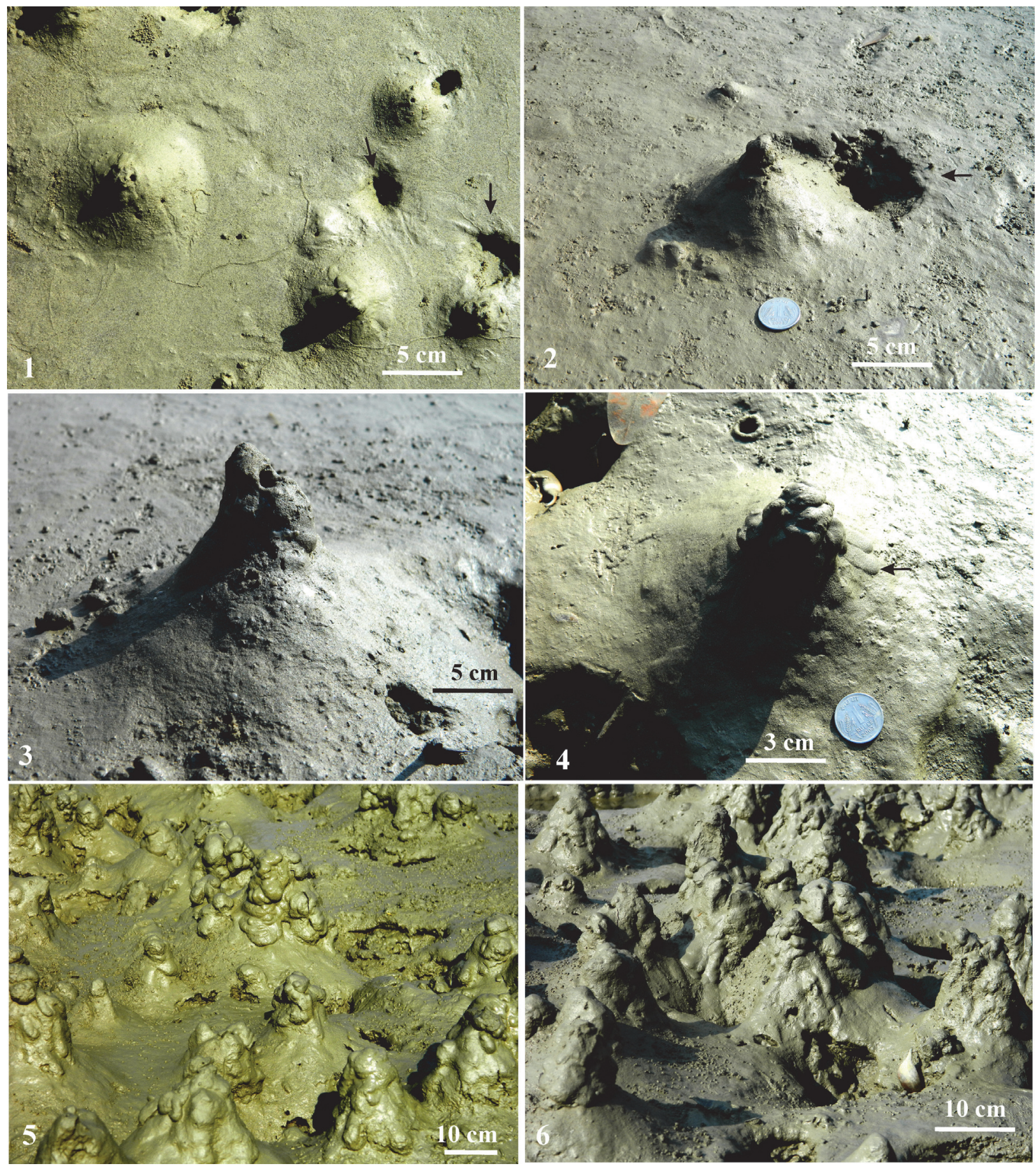

FIGURE 5. 1-6. Photographic illustrations arranged in order of gradual morphological transformation of simple (1) to compound mud-mounds (5-6) highlighting some possible morphological variants. Note greenish brown biomat coating on mud-mounds ( 1 and 5 ) that are microbially stabilized. The grey coloured mounds are yet to be stabilized.

depressions (Figure 8.1-2), mud lumps (Figure 3.7), rolled-out mud balls (Figure 8.3) and broken mud clasts (Figure 4.2). During low tide new mounds were observed to be formed to compensate the loss of burrowing habitat. The crabs try to maintain a balance between loss of dwelling place during high tide and formation of new burrows during low tide.

The above observations were made during the winter month of December when sea (tidal range between $4 \mathrm{~m}$ to $5 \mathrm{~m}$ and centimetric wave amplitude in mud-mound region) and climatic (no 

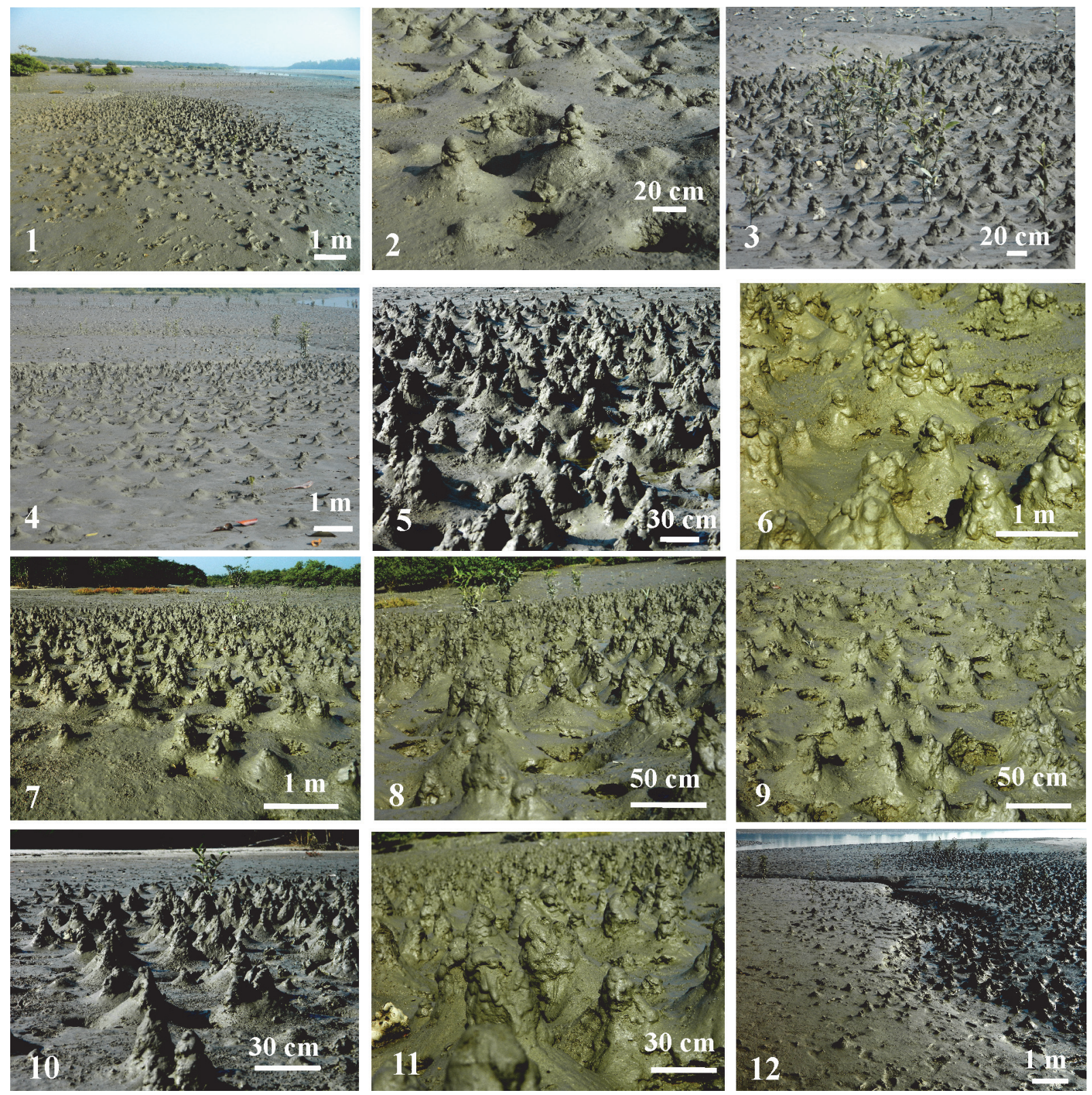

FIGURE 6. 1. A cluster of predominantly simple mud-mounds produced in high ground. 2-4. Photographs showing field occurrences of predominantly simple mud-mounds in higher ground. 5-11. Photographs showing field occurrences of predominantly compound mud-mounds in low ground. Note greenish brown biomat coating on mud-mounds (6-9 and 11) as a part microbial stabilization process. 12. Photograph illustrating ground elevation-based distribution of simple and compound mounds. (Note size variations, population density variations, surficial features, substrate ruggedness, variation in substrate elevation and different morphotypes of mud-mounds as observed in natural populations.)

rainfall, temperature range $19-28^{\circ} \mathrm{C}$ and wind velocity $\sim 30 \mathrm{~km} / \mathrm{hour}$ during day time as per Port Trust of India database) conditions remained fairly normal. Detailed characterization and replication of impacts of tide level due to climatic changes (e.g., during summer, monsoon and pre-monsoon storm events) on the mud-mound-building processes of Uca are important, but constitute altogether a dif- ferent and much complex and wider aspect of neoichnological study, which is beyond the objectives of the present paper.

\section{Influence of Ground Level}

Micro-topographically the study area (Figure 2.1-2) contains distinctive high and low grounds. The measured level difference between high and 


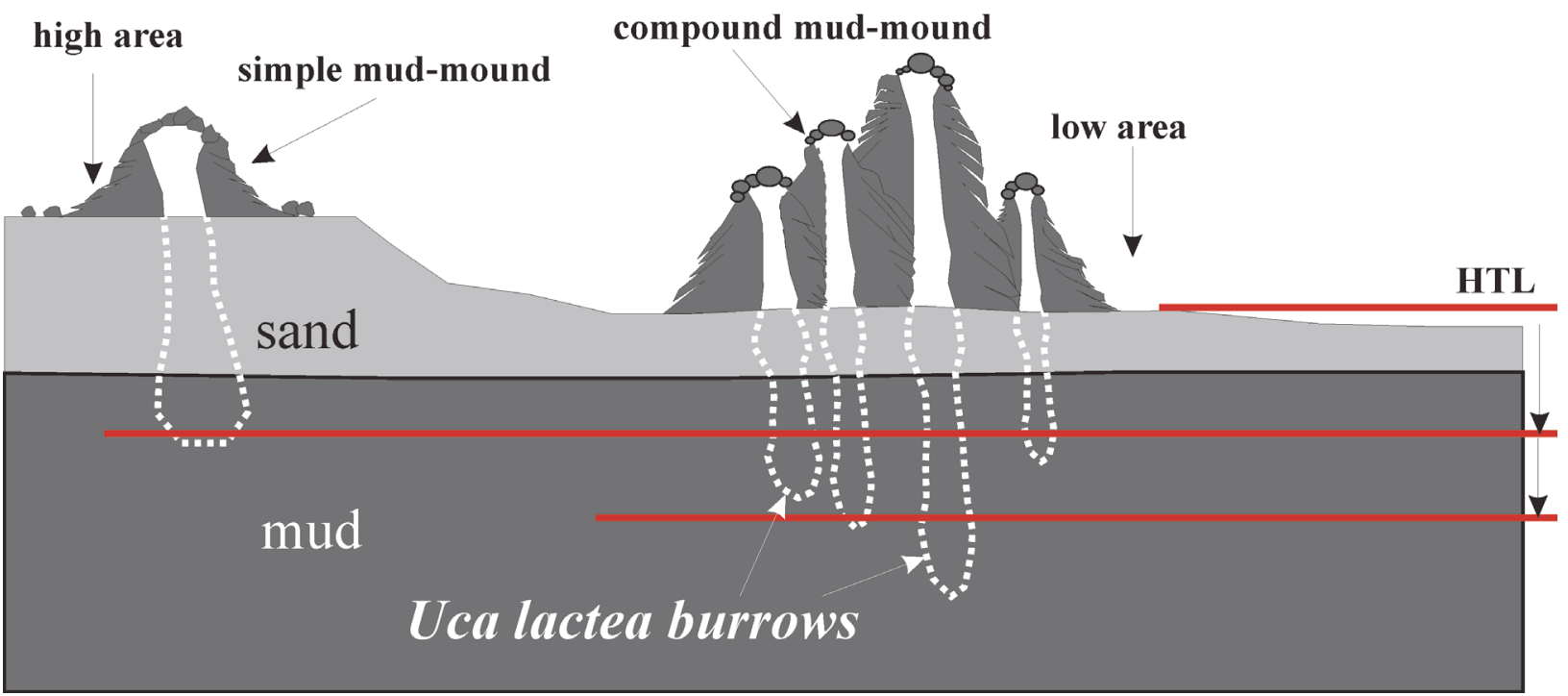

FIGURE 7. Schematic illustration of Uca lactea mud-mound building process as controlled by ground elevation and tidal recession. HTL stands for high tide level.

low grounds varies between 10 and $20 \mathrm{~cm}$. The low ground represents the base of small runnels or creeks flowing down into estuary water. A quantitative survey on mound heights and types (total 149 numbers; Figure 9) across high and low grounds within the sample study area of about $300 \mathrm{sq} \mathrm{m}$ (Figure 2.1) reveals that simple mounds dominate over compound mounds (105 vs. 8) in high grounds and vice versa in low grounds (30 compound vs. 6 simple mounds). The average population density of simple mounds in high ground is 2$3 / \mathrm{sq} \mathrm{m}$ area, while it is 7-9/sq $\mathrm{m}$ area for the compound mounds in low ground (Figures 2.1, 6.12). Moreover, average vertical height of simple mounds is always less than that of compound mounds irrespective of ground height $(11 \mathrm{~cm}$ against $14 \mathrm{~cm}$ in low ground vs. $4 \mathrm{~cm}$ against 7.5 $\mathrm{cm}$ in high ground; Figure 9). These readings also suggest that height of mounds, simple or compound, is greater in low ground (Figures 2.1, 6.12). In other words the volume of oozed out mud is more in low ground than that in high ground. This is explained by the fact that the local ground water level drops with receding tidal water level and the subsurface sediment (mud layer in present case) gets dewatered or dried up earlier below high ground than below low ground. This is evidenced by rapid and continuous oozing out of mud slur and consequent growth of compound mounds in low ground during neap tide interval despite cessation of mound building process in high ground (Figure 7). So, the volume of mound is a measure of the subsurface moistness of the mud layer (or forma- tion of mud slur) rather than the amount of vertical excavation. This is contrary to the idea that the volume of the burrow mouth sediment heap is a measure of subsurface burrow volume as in the case of Ocypode burrows in nearby dry sands beach. The size of the mud-mounds, thus, formed was observed to be largest in low ground during neap tides (Figure 6.5-10). This is true for the sediment mounds grown around burrow mouths of intertidal benthic crabs in Korean mud flats (Lee and Koh, 1994).

\section{Influence of Mangrove Vegetation}

Uca lactea ecologically belongs to mangrove communities. But, they construct mud-mounds in open substrate having thinly populated mangrove vegetation (Figure 2.1). There may be many reasons for this. Firstly, they avoid subsurface obstruction of root systems for quick burrowing and removal of mud slur. This suggests that vegetation does not provide structural support for their burrows or a refuge from predators. Secondly, these crabs need visual landmarks as well as employ visual signals and hence avoid thickly vegetated habitats that hinder visibility. Thirdly, they avoid living within forest because their waving behavior during mating makes them conspicuous to predators, as in the case with $U$. marionis in this area (De, 2009). Effects of vegetation on burrowing differ among different species of Uca (Nobbs, 2003). Being Australian intertidal mangrove communities, Uca flammula Crane, 1975), Uca signata (Hess, 1865) and Uca elegans (George and Jones, 1982) 

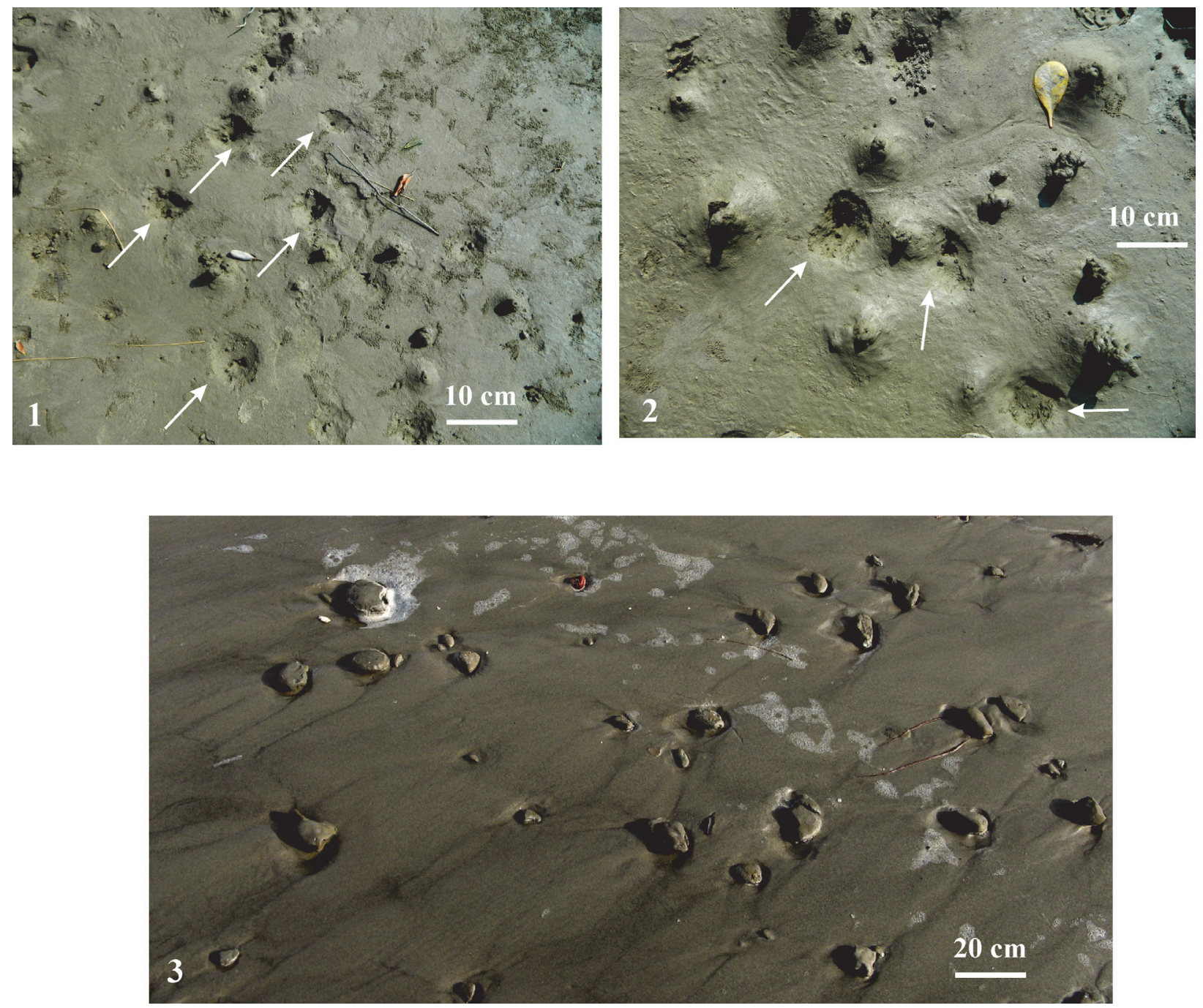

FIGURE 8. 1-2. Photographic illustrations of collapsed mounds (arrowed; circular to irregular depressions with central burrow opening(s) as observed immediately after high tide. 3. Rolled out mud balls, lumps and clasts derived from collapsed mud-mounds by tidal action.

live in forest, edge and clearing habitats, respectively (Nobbs, 2003). Mud-mounds are absent in open sandy beach surface wherein several species of the crab genus Ocypode, polychaete Diopatra cuprea (Bosc, 1802), bivalves and gastropods thrive in large numbers because of the absence of exploitable muddy substrate on or subsurface within the burrowing limit of Uca.

\section{ASSOCIATED LEBENSSPUREN}

Uca lactea mud-mounds in the study area form characteristic natural associations with several types of traces produced by other organisms. Of these, the most conspicuous are the trails of Turritella spp. (gastropods), especially in the low moist areas (Figure 4.4). This is typical of the delin- eated Uca-Turritella subzone of the Bay of Bengal coast (De, 2009). The Uca-Turritella association can be linked to their ubiquitous liking for muddy substrates (De, 2000, 2009). The next abundant traces belong to unidentified worms that produce two types of lebensspuren in relatively dry muddy areas: finer, non-branching and radiating (Figure 4.5) and coarser, branching and knobby sub-horizontal burrow (Figure 4.6) systems.

\section{PRESERVATION AND ROLE OF BIOMATS}

Biomats in sedimentary sequences (Proterozoic to Recent) acted as a very good substrate stabilizer and offered excellent preservation ground for even the most delicate fossils and ichnofossils (Gehling and Rigby, 1996; Seilacher, 1999). Pres- 


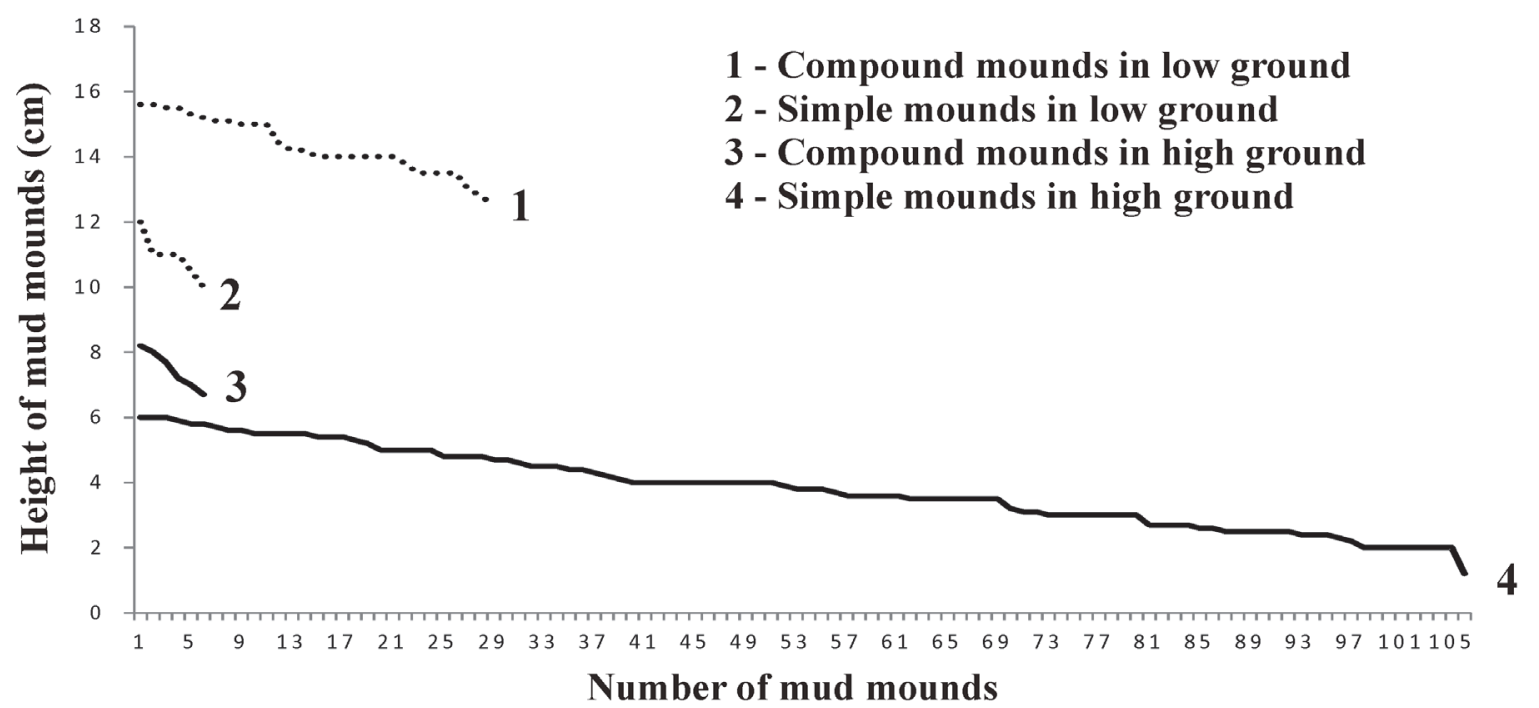

FIGURE 9. Vertical height variation curves of simple and compound mud-mounds (total 149 numbers) of Uca lactea in low and high grounds. Curve 1 - compound mounds (30 numbers with average height $14 \mathrm{~cm}$ ) in low ground; Curve 2 simple mounds ( 6 numbers with average height $11 \mathrm{~cm}$ ) in low ground; Curve 3 - compound mounds ( 8 numbers with average height $7.5 \mathrm{~cm}$ ) in high ground and Curve 4 - simple mounds (105 numbers with average height $4 \mathrm{~cm}$ ) in high ground. Note shorter height of simple mounds relative to compound mounds irrespective of ground height and higher population of simple mounds in high ground and compound mounds in low ground.

ervation of delicate soft bodied Ediacaran biota in the Neoproterozoic biomats is a classic example in this context. The outer surface of sand volcanoes produced by shrimp Glypturus acanthochirus (Stimpson, 1866) in Pleistocene carbonate sandflats of the Bahamas were reported to be stabilized by microbial mats (Curran and Martin, 2003). The Bay of Bengal Sea is known for post-monsoon algal blooms (D'Silva et al., 2012). As a result, greenish-brown coloured coating of biomats is developed all over the intertidal zone of the study area. Although subsequent hydrodynamics destroy a large part, biomats in some protected patchy areas escape erosion and get preserved within sediment. It was observed that the sticky biomats on drying during low tides produced a thin and semi-rigid protective cover that stabilized the mudmounds (Figures 5.5, 6.6-9) and helped them retain their form and surficial features during periods of tidal inundation. In other words, the biomats, sedimentary products of modern algal bloom, enhance preservation possibility of mud-mounds and other associated lebensspuren. De (2009) did not report stabilization of Uca marionis mud volcanoes by biomats from the studied beach sector. Field observation also suggests that the mudmounds in fact get preserved at places within sedimentary sequences, especially when covered by beach or aeolian sands following microbial stabilization.

Ancient intertidal fiddler crab burrows (Curran and Frey, 1977; Humphreys and Balson, 1988; Curran and White, 1991) possess definitive modern analogues from varied coastal shallow marine environments (Chakraborti and Hertweck, 1992; Chakraborti, 1993; Gingras et al., 2000; De, 2000, 2005). This analogy suggests high preservation potential of the modern counterparts. In fact, numerous records of fossilized burrows of Uca origin are known (Shinn, 1968). On the contrary, fossil evidence of burrow mouth sedimentary features are extremely rare considering the fact that burrowing is quantitatively compensated by dumping of excavated sediments around burrow openings in various manners. Fossil evidence of biogenic fecal pellet mounds from the Quaternary Miliolites of Saurashtra, western India (Chakraborti and Baskaran, 1989) and callianassid sand mounds from the Pleistocene of the Bahamas (Curran and Martin, 2003) are two rare examples in this context. Although fossil evidence of described mud-mounds is absent or unidentified till now, the above examples coupled with observed microbial stabilization in modern settings indicate their possible preservation in rock records as such or as various taphonomic variants. Records of innumerable biogenic 
mud-mounds of non-crab origin (see later) from the geologic past also support the above opinion.

Taphonomic expressions of preserved Uca lactea mud-mounds may include: 1) discrete mounds resting over burrowed sand layers; 2 ) vertically burrowed (Skolithos) sand unit underlain by thick mud layer and overlain by thin bioturbated mud layer with rolled out mud balls, mud cones, mud lumps and pellets; and 3) a bioturbated mud layer with upper surface being extremely rugged and microbially stabilized. Other taphonomic variants, however, may also occur. The present study, thus, provides firsthand information applicable towards identification of $U$. lactea mud-mounds and their taphonomic variants in rock records.

\section{MUD-MOUNDS: A COMPARATIVE ANALYSIS}

This section focuses on comparative analysis of the studied modern Uca lactea mud-mounds with mud-mounds from the geological past, modern Uca marionis mud volcanoes of the Bay of Bengal coast (De, 2009) and other similar modern burrow mouth features in the light of geological settings, morphology and genesis.

\section{Mud-Mounds from the Geological Past}

Mud-mounds of varied size and morphology are very common in geological records ranging from lower Palaeozoic to Quaternary. Their genesis has so far remained a subject of fierce debate. Although the majority of these are attributed to biogenic processes (reef and mat building), some are linked to plate margin tectonics and hydrocarbon fields. A few are interpreted as products of combined biological and physical processes. For example, Hauterivian marine calcareous mud-mounds of southeastern Spain (Arias et al., 1995) and Upper Visean mud-mounds of Guadiato Valley, southwestern Spain (Rodríguez-Martínez et al., 2012) are interpreted as microbial buildups. The origin of Middle Jurassic stromatactis mud-mounds in the Pieniny Klippen Belt (Carpathians) has been linked to activities of sponge (Aubrecht et al., 2009). Late Devonian isolated or coalescing mud-mounds (synoptic relief greater than $2 \mathrm{~m}$ ) occurring in proximal fore-reef slope settings in the Canning Basin, Western Australia, have been attributed to microbial reef framework construction in a high energy setting (Webb, 2001). High relief carbonate mudmounds of the Devonian Neuville Formation, southern Belgium, and Ordovician Kullsberg Limestone, central Sweden, have been referred to inorganic origin (Riding, 2002). Sager et al., (2003) linked gigantic mud-mounds of the northern Gulf of
Mexico to hydrocarbon seepage. Krause (2001) inferred the Ordovician Meiklejohn Peak lime mudmounds of Bare Mountain Quadrangle, Nevada, USA, to be submarine frost heave structures. Mud volcanoes, gas chimneys, pockmarks and mounds (100-900 $\mathrm{m}$ in diameter) in the Nile deep-sea fan (Eastern Mediterranean) are attributed to fluidreleasing structures on the seabed (Loncke and Mascle, 2004). Biogenic mud-mounds with stromatactis (a series of elongated cavities, with curved or irregular tops and flat bases, filled with calcite cements) in the Devonian sedimentary basin of Montagne Noire (France) were attributed to diverging plate margin tectonics (Bourrouilh et al., 1998). Late Maastrichtian chalk mounds, Stevns Klint, Denmark are inferred as combined physical and biogenic structures (Anderskouv et al., 2007). Bourrouilh (2000) analyzed Devonian and Cretaceous mud-mounds of southern France on divergent extensional and transform plate margins in terms of ore and oil formation without highlighting the genesis of the mounds. Unlike the present mud-mounds, all these ancient mudmounds are structurally much bigger, generally calcareous, associated with diverging plate margin and oil fields and deep sea origin. Many of them possess filled in curved and irregular cavities (stromatactis) that are different in all respect from the burrow tubes central to $U$. lactea mud-mounds of the study area. This comparison suggests absence of ancient analogue of $U$. lactea mud-mounds; although they are expected to be preserved in post-Jurassic shallow marine sequences wherein lithified burrows of quasimarine crabs are preserved in plenty. This omission in fossil records is enigmatic and perhaps requires further research to identify their ancient analogues and possible taphonomic variants as mentioned earlier. The present study is important in this regard.

\section{Uca marionis Mud Volcanoes}

The Bakkhali Uca lactea mud-mounds are the product of similar special substrate conditions that prevail at several locations along the Bay of Bengal coast, especially around estuary mouths. Uca marionis under similar conditions produce mud volcanoes in this coast (De, 2009). Uca lactea mudmounds bear closest possible similarity in morphology, internal makeup, facies characteristics and biotic and neoichnologic association with $U$. marionis mud volcanoes (Table) because of similarities in burrowing mechanism, substrate conditions, geomorphic setting and liking for muddy substrate. Although the basic mechanisms and purpose of 
TABLE. A comparative analysis of Uca lactea mud-mounds (present study) and Uca marionis mud-volcanoes (De, 2009) produced in the Bay of Bengal coast, India.

Observed traits

Highest population density

Average vertical height of mounds

Mound height variation

Mound building process control

Mound stabilization factor

Burrows within compound mounds

Maximum vertical height of mound centric burrow

Association with worm burrows

Mound collapse during high tides

Morphology of simple and compound mounds
$U$. lactea mud-mounds

9/sq m.

$12 \mathrm{~cm}$

Increases from high to low ground

Tide and mangrove vegetation

Microbially controlled

Close spaced, but not connected

$21 \mathrm{~cm}$ because of higher position of subsurface mud layers

Present

Occurs

Cone and multiple cone
U. marionis mud volcanoes

26/sq m.

$8 \mathrm{~cm}$

Independent of ground undulations

No such control

No microbial control

Close spaced, but connected at the base

$29 \mathrm{~cm}$ because of lower position of subsurface mud layers

Absent

Occurs

Cone and multiple cone formation of mud volcanoes and mud-mounds in the Bay of Bengal coast are the same, several subtle differences (Table) between these two features were observed. Overall morphological similarities claim their grouping within a single ichnotaxon.

\section{Other Similar Burrow Mouth Features}

The Uca lactea mud-mounds are externally similar to Callianassa sand volcanoes described from Aldabra (Farrow, 1971). They differ in sediment constituents (mud vs. sand) and internal burrow structure (simple I-shaped vs. branching treelike). The substrate condition for sand volcanoes is reversed (mud layers overlap sand layers) relative to the present condition. However, Uca mud chimneys described by Farrow (1971) as diagnostic features of mangrove mudflats and creek facies in Aldabra back-reef and lagoonal environments, are very much similar sedimentologically and morphologically to those produced by Uca lactea in the current study area. Similar chimneys are also produced by Uca marionis in the adjoining beach sectors of the Bay of Bengal coast (De, 2009). Unlike Uca lactea mud-mounds, Thalassinidean shrimp in intertidal carbonate sandflats (Pleistocene) of the Bahamas produce sand volcanoes and very large composite sand mounds (Curran and Martin, 2003). Present mud-mounds are also distinctive from $U$. marionis fecal pyramids reported from mangrove creeks and mudflats of Aldabra Atoll (Farrow, 1971), trumpet-like burrow opening of $U$. formosensis (Rathbun, 1921) of Taiwanian tidal mudflats (Dörjes, 1978) and decapod fecal pellet mounds of the Quaternary Miliolites of Saurashtra, western India (Chakraborti and Baskaran, 1989).
The studied mud-mounds are genetically and structurally different from the mud volcanoes or mounds of Andaman Islands that are associated with subduction zone and hydrothermal activities.

The above analysis suggests that Uca lactea mud-mounds have so far no reported ancient analogue, although they can be well preserved like other mud-mounds of non-crab origin. They resemble modern Uca marionis mud volcanoes, but with several dissimilarities. Mud-mounds and mud volcanoes of Uca are not reported from modern coastal littoral settings of other parts of the world, despite the very wide zoogeographic distribution of this crab genus that includes nearly 100 species.

\section{GEOLOGICAL SIGNIFICANCE}

Neoichnology is key to palaeoichnology. The majority of the widely accepted palaeoichnological interpretations are founded on or justified by analogous neoichnological data. Neoichnological characterization of discussed crab mud-mounds is essential for various geological interpretations including recognition of their ancient analogues. This section deals with the geological significance of present neoichnological observations that are very likely to be made in rock records, partly or wholly.

\section{Recognition of Ancient Decapod Burrows and Mud-Mounds}

In post-Jurassic marine littoral facies, crabs are considered as very important geologic agents (Frey et al., 1984) for their selective adaptability, specific diversity, wide variation in lebensspuren (ichnodiversity), bioerosional capability and nutri- 
ent cycling competency in ecosystems (De, 1998; Mokhtari et al., 2008). Identification of fossil crab burrows has always remained problematic especially when crabs, lobsters, shrimps and stromatopods construct morphologically similar burrows in sediments that lack their body fossils (De, 2000). Even then, fossil burrows from the Upper Cretaceous of British Columbia (Richards, 1975), MioPliocene of Japan and Australia (Jenkins, 1975), Oligocene of Egypt (Bown, 1982), Pleistocene of USA (Curran and Frey, 1977) and India (Chakraborti et al., 1993) and Holocene relicts from the Georgia coast (Frey and Basan, 1981) have been firmly attributed to different crab genera of which Uca is a prominent member depending on several sets of morphological and circumstantial evidence (De, 2000). The present study highlights additional features that can be used to recognize fossil burrows of Uca. These are the presence of: 1) mud-mounds (simple and compound) or mud chimneys at burrow heads; 2) collapsed mudmounds with associated mud balls, clasts and lumps in intertidal mudflat facies; and 3) simple burrows in association with bilobed trails and horizontal - subhorizontal branching or nonbranching worm burrows in muddy substrate. Organisms other than Uca spp. producing these features are not known to date.

Although fossil mud-mounds of fiddler crabs are not known, the present neoichnological characterization of Uca lactea mud-mounds contributes new information to the ichnological database for ready recognition of their ancient analogues, if found. These are discussed morphological and size parameters, microbial stabilization factor, special substrate condition, influence of tidal action and ground elevation and open substrate without thickly populated mangrove roots. Furthermore, close association of biomats, bilobed trails and worm burrows (i.e., ichnogenus Taphrhelminthopsis, Planolites and Thalassinoides) strengthens identification of fossilized mud-mounds. Such an ichnological association, although expected to be preserved within coastal ichnofacies (i.e., Skolithos and Psilonichnus), has not been explored so far. The highlighted subtle differences between $U$. lactea mud-mounds and $U$. marionis mud volcanoes (De, 2009) of the Bay of Bengal coast can be applied to differentiate them in rock records. Moreover, the presented data help distinguish them from mud-mounds genetically linked to algal and sponge buildups, diverging plate margin tectonics and hydrocarbon or hydrothermal seepage.

\section{Ichnotaxonomy and Ichnofacies Analysis}

Simple, I-shaped and unbranched burrows (Figure 3.2) and mud chimneys (Figure 4.2-3) produced by $U$. lactea in the study area are referred to ichnofossils Skolithos and Ophiomorpha, respectively. Among the associated lebensspuren the bilobed Turritella spp. trails (Figure 4.5) and subhorizontal nonbranching and branching worm burrows (Figure 4.7-8) correspond to ichnogenus Taphrhelminthopsis, Planolites and Thalassinoides, respectively. Root traces correspond to rhyzolith. Because of their ubiquitous mud-loving nature, burrow mouth features of many species of Uca are made up of mud. These features include simple and compound mud-mounds, mud chimneys and semidomes (for $U$. lactea); simple and compound mud volcanoes, mud chimneys, fecal pyramids and fecal heaps (for U. marionis) and semidomes and trumpet structures (for U. formosensis). Sand volcanoes and very large composite sand mounds of Callianassa and Thalassinidean shrimp are known. These features, like crab burrows, exhibit characteristic and definitive ranges of morphological and sedimentological variations that are amenable to ichnotaxonomy. None other than mud chimney (Ophiomorpha) has been treated ichnotaxonomically so far. The present work suggests genetic, morphological and sedimentological identity between $U$. marionis mud volcanoes and $U$. lactea mud-mounds. These two features and their variations or transitions warrant ichnotaxonomic grouping within ichnogeneric level.

In the studied region endobenthic burrowing/ boring and other trace-making invertebrate populations include quasiterrestrial crabs (Ocypode spp., Ilyoplax pusillus de Haan, 1835, U. marionis, U. lactea and Charybdis rostrata Milne-Edwards, 1861), bivalves, gastropods (Turritella spp., Telescopium telescopium Linnaeus, 1758 and Cerithidae obtusum Lamarck, 1822) and the polychaete Diopatra cuprea Bosc, 1802 (De, 2000). Six coastparallel and mutually overlapping ichnozones have been delineated each of which possesses diagnostic sedimentological, ichnological, environmental and geomorphic characteristics (De, 2000). Of these the Uca-Turritella ichnozone represents a mangrove vegetated and clay-rich backswampsaltmarsh-mudflat complex (De, 2009) wherein Ishaped vertical Uca burrows (Skolithos), Uca mudmounds/mud volcanoes (unnamed) and bilobed gastropod trails (Taphrhelminthopsis) occur associated with substratal worm burrows (Planolites and Thalassinoides) and mud chimneys (Ophiomor- 
pha). This ichnocoenose together with another ichnocoenose defined by $\mathrm{J}, \mathrm{U}, \mathrm{Y}$ and multibranched Y-shaped burrows (Psilonichnus, Macanopsis and Arenicolites) of crabs other than Uca in adjacent beach sand facies constitute a typical Psilinichnus ichnofacies that represents moderate to low energy supralittoral and upper littoral (intertidal foreshore) settings (Pemberton et al., 1992; Buatois et al., 1998; Buatois and Mángano, 2000). Further ichnotaxonomic and environmental characterization of Psilinichnus ichnofacies is possible with the incorporation of $U$. lactea mud-mounds and $U$. marionis mud volcanoes (De, 2009) as unique ichnotaxon diagnostic of estuary mouth mudflats distal to mangrove forest.

\section{Depositional Palaeoenvironment and Palaeogeography}

Recognition of shoreline facies in ancient deltas is important for basin analysis, palaeoenvironmental reconstruction, delineation of palaeoshoreline and hydrocarbon exploration. Trace fossils, as ideal environmental indicators, have been confidently applied to recognize palaeoshoreline facies in the Middle Miocene Korytonica Basin of Poland (Radwański, 1977); Pleistocene basins of Carolina, Georgia, Florida and Kenya (Curran and Frey, 1977) and upper Book Cliffs (Howard, 1972). These applications are based primarily on delineation of Psilonichnus ichnofacies that is typically transitional between continental palaeosol Coprinisphaera and high-energy foreshore marine Skolithos ichnofacies (Pemberton et al., 1992; Buatois et al., 1998; Buatois and Mángano, 2000; Genise et al., 2000).

The Psylonichnus ichnofacies of the studied region represents, over all, moderate to low energy supralittoral and upper littoral (intertidal foreshore) environments dwelled predominantly by quasiterrestrial crabs. One ichnocoenose within the domain of this ichnofacies is composed of an intimate assemblage of Uca mud-mounds (ichnotaxonomically unnamed), Skolithos burrows of crab origin, Ophiomorpha (mud chimneys atop crab burrows), Planolites (subhorizontal unbranched worm burrows), Thalassinoides (subhorizontal branched worm burrows) and Taphrhelminthopsis (bilobed gastropod trails). Within a shoreline facies this ichnocoenose represents typical intertidal mudflat settings proximal to estuaries with thin mangrove population. Presence of collapsed mounds suggests infrequent higher energy conditions and complete inundation by spring tide. Occurrence of rolled out mud balls suggests tidal action. In situ mud-mounds can be used as good geopetal (cone head pointing up). Volume of mud-mound is directly a measure of moistness of subsurface mud. Microbial stabilization of mud-mounds suggests seasonal algal bloom in sea water. This new information can be added to the ichnological database for application to geologic past to assist with palaeoenvironmental and palaeogeographic interpretations.

\section{GEOTECHNICAL SIGNIFICANCE}

Like Uca marionis mud volcanoes of the Bay of Bengal coast (De, 2009), the U. lactea mudmounds can be considered as another ichnological tool having geotechnical importance. Very specific substrate conditions (soft and moist mud layer below relatively rigid and dry sand cover) required for their development in coastal mudflats around estuary mouths makes them a useful indicator of unstable coastal tract. The top cover of a thin layer of rigid sand is very deceptive and gives a false idea of substrate stability. Under influence of higher hydrodynamic forces this sand layer is vulnerable to rapid erosion exposing subsurface soft mud. Recognition and careful exclusion of unstable coastal tract are essential in planning, protection and execution of all coastal developmental programs, such as construction of dams, harbors, hydroelectric power stations, jetties, coastal highways, bridges and beach resorts. Application of this ichnological tool also saves money, time and labour. It can replace costly and time-consuming physical techniques. Wide zoogeographic distribution of $U$. lactea across tropical and subtropical sea coasts increases the application potential of this ichnological tool.

\section{CONCLUSIONS}

Neoichnological observations on the burrowing activities of quasiterrestrial fiddler crabs Uca lactea of the Bay of Bengal coast have revealed their very conspicuous mud-mound building life habit in specific substrate conditions (soft aqueous mud covered deceptively by rigid, dry and thin layers of sand) under the influence of tidal action in coastal mudflat proximal to estuary mouths. These crabs, like associated Uca marionis, construct protective mud-mounds at their burrow heads during neap tides through repeated oozing out of mud slur accumulated at their burrow base positioned at the subsurface mud layer. Several simple mounds amalgamate into a compound mound in low ground having a thick burrow population. Tidal 
recession and lowering of local groundwater levels control the oozing process of mud slur. The crabs prefer burrowing in thinly vegetated mudflats to avoid root obstruction. Post monsoonal algal blooms form biomats over the substrate features. The mounds are partially stabilized by microbial mats and preserved under freshly deposited sand layers. During high tide some of the mounds collapse and rolled out mud balls, lumps and clasts are produced. This loss of habitat is compensated by immediate reconstruction of fresh burrows and mud-mounds during the next low tide. Uca lactea also produce mud chimneys and feeding pellets in close association with Turritella spp. trails and subhorizontal worm burrows (branching and nonbranching).

Considering present observation of microbial stabilization and partial preservation of the mudmounds; fossil records of decapod burrows, sand mounds, pellet mounds, feeding pellets and mud chimneys and the fact that infaunal crab burrowing accompanies dumping of excavated materials around the burrow mouth, it is concluded that $U$. lactea mud-mounds have considerable preservation potential and can be expected in post-Jurassic shallow marine littoral facies, although exact ancient analogues are not known or recognized so far.

The present study provides new evidence to recognize fossil burrows of Uca, such as presence of mud-mounds (simple and compound) or mud chimneys at burrow heads, collapsed mud-mounds and associated mud balls, lumps, clasts and pellets in intertidal mudflat facies.

The present neoichnological characterization of Uca lactea mud-mounds contributes new information to the ichnological database for ready recognition of their ancient analogues. It highlights genetic, morphological and sedimentological identity as well as subtle differences between $U$. marionis mud volcanoes and $U$. lactea mud-mounds. These two features are morphologically similar enough to claim grouping within a unique ichnotaxon.

The simple I-shaped burrows central to the mud-mounds, mud chimneys, associated bilobed gastropod trails and substratal and subhorizontal worm burrows define a new ichnocoenose typical of mangrove vegetated littoral mudflat facies within the ambit of shallow marine Psilonichnus ichnofacies. This ichnocoenose in the fossil record is defined by Skolithos, Taphrhelminthopsis, Ophiomorpha, Planolites and Thalassinoides associa- tions with sparse rhyzoliths. Further ichnotaxonomic and palaeoenvironmental characterization of Psilinichnus ichnofacies is possible with the incorporation of $U$. lactea mud-mounds as diagnostic ichnoform of estuary mouth mudflats distal to mangrove forest and ancient shoreline.

The presence of collapsed mounds and rolled-out mud balls suggests higher energy conditions and tidal action and inundation. In situ mudmounds can be used as good geopetal (cone head pointing up). The volume of the mud-mound is directly a measure of the moistness of subsurface mud rather than the amount of excavation or burrow volume. Microbial stabilization of mud-mounds suggests seasonal algal bloom in sea water. This new information can be added to the ichnological database for application to the geologic past.

The requirement of very specific substrate conditions allows Uca lactea mud-mounds to be considered as ichnological indicators of unstable coastal tracts. Their wide zoogeographic distribution, in addition, increases the applied value of this ichnological tool.

\section{ACKNOWLEDGEMENTS}

The author expresses her gratitude to C. De, Ex-Director of Geological Survey of India for guidance in field and manuscript preparation, to the Head of the Department of Geosciences, Presidency University, Kolkata for constant encouragement and to M. Debroy, Zoologist of Zoological Survey of India, Kolkata for taxonomic identification of the crab samples.

\section{REFERENCES}

Alcock, A. 1900. Material for a carcinological fauna of India. No. 6. The Brachyura, Catometona or Graosoidea. Asiatic Society of Bengal 2. Natural Science, 69:272-456.

Allison, M.A. 1998a. Geologic framework and environmental status of the Ganges-Brahmaputra Delta. Journal of Coastal Research, 14:826-836.

Allison, M.A. 1998b. Historical changes in the GangesBrahmaputra Delta Front. Journal of Coastal Research, 14:1269-1275.

Anderskouv, K., Damholt, T., and Surlyk, F. 2007. Late Maastrichtian chalk mounds, Stevens Klint, Denmark - Combined physical and biogenic structures. Sedimentary Geology, 200:57-72.

Arias, C., Masse, J.P., and Vilas, L., 1995. Hauterivian shallow marine calcareous biogenic mounds: S.E. Spain. Palaeogeography, Palaeoclimatology, Palaeoecology, 119:3-17. 
Aubrecht, R., Schlögl, J., Krobicki, M., Wierzbowski, H., Matyja, B.A., and Wierzbowski, A. 2009. Middle Jurassic stromatactis mud-mounds in the Pieniny Klippen Belt (Carpathians)_A possible clue to the origin of stromatactis. Sedimentary Geology, 213:97112.

Bakshi, S.K., Ray, T.K., and De, C. 1980. On the workings of some crabs on the sandy beach of Western Sundarban, Bengal Delta, India. Journal of Geological Society of India, 21:184-187.

Bandopahdyay, A. and De, C. 2000. Algal micro-boring on ooids: an evidence of Holocene sea transgression in eastern India. Indian Journal of Marine Science, 29:181-184.

Basan, P.B. and Frey, R.W. 1977. Actual palaeontology and neoichnology of salt marshes near Sapelo Island, Georgia, p. 41-70. In Crimes, T.P. and Harper, J.C. (eds.), Trace Fossils. Geological Journal Special Issue, 9. Steel House Press, Liverpool.

Bertness, M.D. and Miller, T. 1984. The distribution and dynamics of Uca pugnax (Smith) burrows in a New England salt marsh. Journal of Experimental Marine Biology and Ecology, 83:211-237.

Bones, L.A. 1983. The Behaviour and Ecology of Hong Kong Fiddler Crabs with Special Reference to Uca lactea and Uca vocans. Hong Kong University Press, Hong Kong.

Bosc, L.A.G. 1802. Histoire naturelle des crustacés, contenant leur description et leurs moeurs; avec figures dessinées d'après nature, Volume 1, Paris, Deterville.

Bourrouilh, R. 2000. Mud mounds on divergent extensional and transform margins: Devonian and Cretaceous examples from southern France, p. 463-483. In Sola, M.A. and Worsley, D. (eds.), Geological Exploration in Murzuq Basin. Elsevier, Amsterdam.

Bourrouilh, R., Bourque, P.A., Dansereau, P., Jan, F.B., and Weyant, P. 1998. Synsedimentary tectonics, mud-mounds and sea-level changes on a Palaeozoic carbonate platform margin: a Devonian Montagne Noire example (France). Sedimentary Geology, 118:95-118.

Bown, T.M. 1982. Ichnofossils and rhizoliths of the nearshore fluvial Jebal Quatrino Formation (Oligocene), Fayum Province, Egypt. Palaeogeography, Palaeoclimatology, Palaeoecology, 40:255-309.

Buatois, L.A. and Mángano, M.G. 2000. Application of ichnology to hydrocarbon prospecting and reservoir characterization. Boletin de informaciones petroleras, 17:65-85.

Buatois, L.A., Mángano, M.G., Maples, C.G., and Lanier, W.P. 1998. Allostratigraphic and sedimentologic application of trace fossils to the study of incised estuarine valleys: an example from the Virgilian Tonganoxie Sandstone Member of Eastern Kansas. Bulletin Kansas Geological Survey, 241:1-27.

Chakraborti, A. 1972. Beach structures produced by crab pellets. Sedimentology, 18:129-134.
Chakraborti, A. 1981. Burrow patterns of Ocypode ceratophthalma Pallas and their environmental significance. Journal of Palaeontology, 55:431-441.

Chakraborti, A. 1993. Ocypode burrows as predictors of ancient shoreline position: New findings from a barred tidal flat. Indian Journal of Geology, 65:15-24.

Chakraborti, A. and Baskaran, M. 1989. Biogenic faecal pellet mounds in Quaternary Miliolites of Saurashtra, India. Palaeogeography, Palaeoclimatology, Palaeoecology, 73:311-315.

Chakraborti, A. and Hertweck, G. 1992. United backfilled burrows: a result of biogenic activities of bubbler crabs in the tropical tidal flats of the Indian coast. Courier Forschungsinstitut Senckenberg, 151:16.

Chakraborti, A., Somayajulu, B.L.K., Baskaran, M., and Kumar, B. 1993. Quaternary Miliolites of Kutch and Saurashtra, Western India: Depositional environments in the light of physical sedimentary structures, biogenic structures and geochronological setting of the rocks. Senckenbergiana Maritima, 23:7-28.

Chattopadhaya, G., Chakraborti, A., and Hertweck. G. 1993. Biogenic structures related to feeding activities of Macoma birmanica from the mangrove areas of the Sagar Island, NE India. Senckenbergiana Maritima, 23:99-107.

Christy, J.H. 1982. Burrow structure and use in the sand fiddler crab, Uca pugilator (Bosc). Animal Behaviour, 30:687-694.

Crane, J. 1975. Fiddler Crabs of the World: Ocypodidae: Genus Uca. Princeton University Press, Princeton.

Curran, H.A. and Frey, R.W. 1977. Pleistocene trace fossils from North Carolina (USA) and their Holocene analogues, p. 139-162. In Crimes, T.P. and Harper, J.C. (eds.), Trace Fossils 2. Geological Journal Special Issue, 9. Steel House Press, Liverpool.

Curran, H.A. and Martin, A.J. 2003. Complex decapod burrows and ecological relationships in modern and Pleistocene intertidal carbonate environments, San Salvador Island, Bahamas. Palaeogeography, Palaeoclimatology, Palaeoecology, 192:229-245.

Curran, H.A. and White, B. 1991. Trace fossils of shallow subtidal to dunal ichnofacies in Bahamian Quaternary carbonates. Palaios, 6:498-510.

De, C. 1997. Study of modern Turritella attenuta trails and burrows on the Bhagirathi River beds and their significance. Indian Minerals, 51:199-206.

De, C. 1998. Biological reworking of sediments by crabs: A cause for erosion of the Digha beach, West Bengal. Current Science, 75:617-620.

De, C. 2000. Neoichnological activities of endobenthic invertebrates in downdrift coastal Ganges Delta Complex, India: Their significance in trace fossil interpretations and Palaeoshoreline reconstructions. Ichnos, 7:89-113.

De, C. 2002a. Application of a biological tool for estimating current annual rates of erosion and deposition in modern coastal environments: A case study in the Bay of Bengal coast. Marine Georesources and Geotechnology, 20:209-220. 
De, C. 2002b. Continental mayfly burrows within relictground in inter-tidal beach profile of Bay of Bengal coast: A new ichnological evidence of Holocene marine transgression. Current Science, 83:64-67.

De, C. 2003. Ichnological evidences of Holocene marine transgression in the Bay of Bengal Coast, West Bengal, India. Proceedings of GEOSAS Seminar, New Delhi. 302-311.

De, C. 2005. Biophysical model of intertidal beach crab burrowing: application and significance. Ichnos, 12:11-29.

De, C. 2009. Uca marionis Mud Volcanoes: a unique Ichnological tool from the Bay of Bengal Coast of India for ready assessment of beach stability. Marine Georesources and Geotechnology, 27:1-17.

De. C. 2010. Sundarban Delta Complex: A special feature. Indian Journal of Geosciences, 63:397-428.

De, C. and Bakshi, S.K. 1981. Geological significance of the burrows produced by the crab Uca marionis on the salt marsh river bank of inner Sundarban Delta Complex, India. Geophytology, 11:80-89.

Deb, M. 1998. Faunas of Bengal: Part Crustacea: Decapoda; Corals. Publication of Zoological Survey of India, Kolkata. State Fauna Series, 3:345-403.

de Haan, W. 1835. Crustacea, p. 1-243. In von Siebold, P.F. (ed.), Fauna Japonica sive Descriptio animalium, quae in itinere per Japoniam, jussu et auspiciis superiorum, qui summum in India Batava Imperium tenent, suscepto, annis 1823-1830 collegit, notis, observationibus et adumbrationibus illustravit. Lugduni Batavorum, Amsterdam.

Dörjes, J. 1978. Sedimentologische und faunistische Untersuchungen an Watteni in Taiwan. II. Faunistische und aktuopaleontologische Studien. Senckenbergiana Maritima, 10:117-143.

D'Silva M.S., Anil A.C., Naik R.K., and D'Costa P.M. 2012. Algal blooms: a perspective from the coasts of India. Natural Hazards, 63:1225-1253.

Eydoux, F. 1835. Nouvelle espèce de Gélasime. Magazine de Zoologie, 5:4.

Farrow, G.E. 1971. Back-reef and lagoonal environments of Aldabra Atoll distinguished by their crustacean burrows. Symposia of the Zoological Society of London, 28:455-500.

Frey, R.W. and Basan, P.B. 1981. Taphonomy of relict Holocene salt marsh deposits, Cabretta Island, Georgia. Senckenbergiana Maritima, 13:111-155.

Frey, R.W., Curran, H.A., and Pemberton, S.G. 1984. Tracemaking activities of crabs and their environmental significance: The ichnogenus Psilonichnus. Journal of Paleontology, 58:333-350.

Gehling, R.G. and Rigby, J.K. 1996. Long expected sponges from the Neoproterozoic Ediacara fauna of South Australia. Journal of Palaeontology, 70:185195.

Genise, G.F., Mángano, M.G., Buatois, L.A., Laza, J.H., and Verde, M. 2000. Insect trace fossil associations in palaeosols: the Coprinisphaera ichnofacies. Palaios, 15:49-64.
George, R.W. and D.S. Jones. 1982. A revision of the fiddler crabs of Australia (Ocypodinae: Uca). Record of the Western Australian Museum Supplement, 14:1-99.

Gingras, M.K., Hubbard, S.M., Pemberton, S.G., and Saunders, T. 2000. The significance of Pleistocene Psilonichnus at Willapa Bay. Washington. Palaios, 15:142-151.

Gingras, M.K., Pemberton, S.G., and Saunders, T. 1999. The ichnology of modern and Pleistocene brackishwater deposits at Willapa Bay, Washington: Variability in estuarine settings. Palaios, 14:352-374.

Gusmão-Junior, J.B. Machado, G.B.O., and Costa, T.M. 2012. Burrows with chimneys of fiddler crab Uca thayeri: construction, occurrence and function. Zoological Studies, 51:598-605.

Hess, W. 1865. Beiträge zur Kenntniss der DecapodenKrebse ost-Australiens. Archiv für Naturgescicthe, 1865:127-173.

Howard, J.D. 1972. Trace fossils as criteria for recognizing shorelines in the stratigraphic records. In Rigby, J.K. and Hamlin, W.M.K. (eds.), Recognition of ancient sedimentary environments. Society of Economic Paleontologists and Mineralogists, Special Publication, 16:215-225.

Howard, J.D. and Frey, R.W. 1975. Estuaries of the Georgia coast, U.S.A. sedimentology and biology. II Regional animal-sediment characteristics of Georgia Estuaries, Senckenbergiana Maritima, 7:33-103.

Humphreys, B. and Balson, P.S. 1988. Psilonichnus (Fürsich) in Late Pliocene subtidal marine sands of Eastern England. Journal of Paleontology, 62:168217.

Jenkins, R.J.F. 1975. The fossil crab Ommatocarcinus corioensis (Cresswell) and a review of related Australian species. Memoirs National Museum of Victoria, 36:33-62.

Kima, T.W., Christy, J.H., and Choe, J.C. 2004. Semidome building as sexual signaling in the fiddler crab Uca lactea (Brachyura: Ocypodidae). Journal of Crustacean Biology, 24:673-679.

Kima, T.W., Keun, K.T., and Choec, J.C. 2010. Compensation for homing errors by using courtship structures as visual landmarks. Behavioral Ecology, 21:836842.

Krause, F.F. 2001. Genesis and geometry of the Meiklejohn Peak lime mud-mound, Bare Mountain Quadrangle, Nevada, USA: Ordovician limestone with submarine frost heave structures-a possible response to gas clathrate hydrate evolution. Sedimentary Geology, 145:189-213.

Lamarck, J.B. 1822. Histoire Naturelle des Animaux sans Vertèbres 7. Paris.

Le Conte, J. 1855. On a new species of Gelasimus. Proceedings of the Academy of Natural Sciences of Philadelphia, 7:402-403. 
Lee, Y.H. and Koh, C.H. 1994. Biogenic sedimentary structures on a Korean mud flat: Spring-neap variations. Netherlands Journal of Sea Research, 32:8190.

Linnaeus, C. 1758. Systema Naturae per Regua Tria naturae. Tomus I. Editio decimal, Reformata. Laurentii Salvii, Stockholm.

Loncke, L. and Mascle, J. 2004. Mud volcanoes, gas chimneys, pockmarks and mounds in the Nile deepsea fan (Eastern Mediterranean): geophysical evidences. Marine and Petroleum Geology, 21:669-689.

Machado, G.B.O., Gusmão-Junior, J.B.L., and Costa, T.M. 2013. Burrow morphology of Uca uruguayensis and Uca leptodactylus (Decapoda: Ocypodidae) from a subtropical mangrove forest in the western Atlantic. Integrative Zoology, 8:307-314. doi: 10.1111/j.17494877.2012.00297.

Mallick, S., Bhattacharaya, A., and Niyogi, D. 1972. A comparative study of the Quaternary formations in the Baitarani Valley, Orissa with those of the Damodar-Ajoy delta area, lower Ganga basin. Proceedings of the Seminar on Geomorphology, Geohydrology and Geotectonics of the Lower Ganga Basin, IIT, Kharagpur, W.B. 91-104.

Mallick, T.K. 1976. Shelf sediments on the Ganges delta. Marine Geology, 22:1-32.

Mallick, T.K. 2006. Crab pellets in the beaches-a firsthand clue for placer exploration, p. 66-70. In Loveson, V.J., Chandrasekhar, N., and Sinha, A. (eds.), Proceedings Development Planning of Coastal Placer Minerals (Placer 2005). Allied Publisher, New Delhi.

Mángano, M.G., Buatois, L.A., Wu, X., Sun, J., and Zhang, G. 1994. Sedimentary facies, depositional processes and climatic controls in a Triassic lake, Tanzhung Formation,Western Henan Province, China. Journal of Paleontology, 11:41-65.

Mayou, T.V. and Howard, J.D. 1975. Estuaries of the Georgia Coast, U.S.A.: Sedimentology and biology.VI. Animal-sediment relationships of a salt marsh estuary-Doboy Sound. Senckenbergiana Maritima, 7:205-236.

Milne-Edwards, H. 1837. Description de quelques Crustacés nouveaux ou peu connus provenant du Musće de M. c. godeffroy. Journal Museum Godeffroy, 1:77-88.

Milne-Edwards, A. 1861. Histoire des crustacés podophthalmaires fossils. Paris: V. Masson.

Mokhtari, M., Savari, A., Rezai, H., Kochanian, P., and Bitaab, A. 2008. Population ecology of fiddler crab Uca lactea annulipes (Decapoda: Ocypodidae) in Sirik mangrove estuary, Iran. Estuarine, Coastal and Shelf Science, 76:273-281.

Nobbs, M. 2003. Effects of vegetation differ among three species of fiddler crabs (Uca spp.) Journal of Experimental Marine Biology and Ecology, 284:41-50.
Nobili, G. 1901. Decapodi raccolti dal Dr. Filippo Silvestri nell'America meridionale. Bollettino dei Musei di Zoologia ed Anatomia comparata della R. Università di Torino, 16:1-16.

Pemberton, S.G., MacEachern, J.A., and Frey, R.W. 1992. Trace fossil facies models: environmental and allostratigraphic significance, p. 47-72. In Walker, R.G. and James, N.P. (eds.), Facies Models: Response to Sea Level Change. Geological Association of Canada, Geotext 1. St Johns.

Radwański, A. 1977. Burrows attributable to the ghost crab Ocypode from the Korytnica Basin (Middle Miocene: Holy Cross Mountains, Poland). Acta Geologica Polonica, 27:217-225.

Rathbun, M.J. 1898. Type description of Uca leptodactyla in The Northrop collection of Crustacea from the Bahamas. Annals of the New York Academy of Sciences, 11:227-228.

Rathbun, M.J. 1900. Results of the Branner-Agassiz expedition to Brazil. I. The decapod and stomatopod Crustacea. Proceedings of the Washington Academy of Sciences, 2:133-156.

Rathbun, M.J. 1921. New species of crabs from Formosa. Proceedings of the Biological Society of Washington, 34:155-156.

Richards, B.C. 1975. Longusorbis cuniculosus: a new genus and species of Upper Cretaceous crab: with comments on Spray Formation at Shelter Point, Vancouver Island, British Columbia. Canadian Journal of Earth Sciences, 12:1850-1863.

Ricketts, E.F. and Calvin, J. 1962. Between Pacific Tides. Stanford University Press, Stanford, California.

Riding, R. 2002. Structure and composition of organic reefs and carbonate mud mounds: concepts and categories. Earth-Science Reviews, 58:163-231.

Rodríguez-Martínez, M., Moreno-González, I., Mas, R., and Reitner, J. 2012. Paleoenvironmental reconstruction of microbial mud mound derived boulders from gravity-flow polymictic megabreccias (Visean, SW Spain). Sedimentary Geology, 263-264:157-173.

Rosenberg M.S. 2001. The systematics and taxonomy of fiddler crabs: a phylogeny of the genus Uca. Journal of Crustacean Biology, 21:839-869.

Sager, W.W., MacDonald, I.R., and Hou, R. 2003. Geophysical signatures of mud-mounds at hydrocarbon seeps on the Louisiana continental slope, northern Gulf of Mexico. Marine Geology, 198:97-132.

Seilacher, A. 1999. Biomat-related lifestyles in the Precambrian. Palaios, 14:86-93.

Shinn, E.A. 1968. Burrowing in recent lime sediments of Florida and Bahamas. Journal of Paleontology, 42:879-894.

Smith, S.I. 1870. Notes on American Crustacea. No. 1. Ocypodoidea. Transactions of the Connecticut Academy of Arts and Science, 2:113-176. 
Stimpson, W. 1866. Descriptions of new Genera and Species of Macrurous Crustacea from the Coasts of North America. Proceedings of the Chicago Academy of Sciences, 1: 46-48.

Warren, J.H. and Underwood A.J. 1986. Effects of burrowing crabs on the topography of mangrove swamps in New South Wales. Journal of Experimental Marine Biology and Ecology, 102:223-235.

Webb, G.E. 2001. Famennian mud-mounds in the proximal fore-reef slope, Canning Basin, Western Australia. Sedimentary Geology, 145:295-315.
Wolfrath, B. 1992. Burrowing of the fiddler crab Uca tangeri in the Ria Formosa in Portugal and its influence on sediment structure. Marine Ecology Progress Series, 85:237-243.

Yamaguchi, T. and Sugakiri, T. 2004. Territory usage and defense of the fiddler crab, Uca lactea (De Haan) (Decapoda, Brachyura, Ocypodidae). Crustaceana, 77:1055-1080. 